\title{
Factors Influencing Dental Caries in HIV/AIDS Patients
}

\author{
Retno Palupi, Agung Sosiawan, Gilang Rasuna Sabdho Wening and Aulia Ramadhani \\ Department of Dental Public Health, Faculty of Dental Medicine, Universitas Airlangga, Surabaya, Indonesia
}

\begin{abstract}
Background. Human immunodeficiency viruses (HIV) / Acquired immunodeficiency syndrome (AIDS) is one of the most significant public health challenges in Surabaya, Indonesia where the greatest number of people living with HIV/AIDS (PLWHA) among key populations is in areas served by Sememi Public Health Center. HIV-infected persons have a greater risk for developing dental caries, such as salivary gland enlargement, and decreased salivary glands function. Given the fact that PLWHA are at high risk of dental caries, utilization of dental health service among PLWHA are still low.
\end{abstract}

Objective. This study aims to know the factors influencing dental caries in HIV/AIDS patients.

Methods. This is a descriptive, cross-sectional study conducted on $16 \mathrm{HIV}$-seropositive individuals. They were asked to complete a WHO questionnaire concerning basic oral health and quality of life. Dental caries was assessed using the Decayed, Missing, and Filled Teeth (DMFT) index. Whole stimulated saliva samples were also collected.

Results. Nine out of 16 respondents had low salivary flow rate (56.3\%). One patient had low DMF-T score (6.3\%) and eight had high DMFT score (50\%). Among seven respondents who had normal salivary flow rate $(43.8 \%)$, two of whom had low DMFT score (12.5\%) and five of whom had high DMFT score (31.3\%).

Conclusion. People living with HIV/AIDS have high DMFT and low salivary flow rate.

Key Words: dental caries, DMF Index, HIV, saliva

\section{INTRODUCTION}

The development of Human Immunodeficiency Virus / Acquired Immuno Deficiency Syndrome (HIV/ AIDS) epidemic continues to rise rapidly in the world, and thus HIV/AIDS remains a global public health problem. In Indonesia, HIV/AIDS is also one of the major health problems, particularly in Surabaya in East Java province.

$\mathrm{HIV}$ is a retrovirus that causes a decline in the human immune system. AIDS is a group of symptoms of illness that occurs when the human immune system weakens because of HIV infection. ${ }^{1}$ In 2016, 7,146 confirmed cases of HIV and 305 cases of AIDS were reported in Jakarta. ${ }^{2}$ Injecting drug users (IDUs), sex workers and spouses /customers, homosexuals, and infants infected from their mothers were found to be among the groups at high risk for HIV infection. ${ }^{1}$

HIV cases are spread out across all districts in Surabaya

Paper presented at the Joint Scientific Meeting in Special Care Dentistry, July 5,t 2019, Amerta Room, 4th Floor, main campus of Universitas Airlangga, Surabaya, Indonesia.

Corresponding author: Retno Palupi

Department of Dental Public Health

Faculty of Dental Medicine

Universitas Airlangga

J. Mayjen. Prof. Dr. Moestopo No. 47 Surabaya 60132 - Indonesia

Email: retno-p@fkg.unair.ac.id so the epidemiology of HIV is a challenge and one of the most complicated health problems in Surabaya. The success of HIV/AIDS prevention in Surabaya will not only provide benefits for Surabaya but also AIDS prevention at the provincial and national levels. ${ }^{3}$

HIV is a virus that infects cells from the immune system. As the infection progresses, the immune system 
becomes weak and people become more susceptible to infection. Gradually the immune system that is infected by the HIV virus will cause the immune function to decline and further be damaged. Patients with impaired immunity will show symptoms related to the opportunistic infection. ${ }^{4}$

In 2017, Sememi Public Health identified the highrisk key population of PLWHA and based on the general medical check-up data, only $12.5 \%$ of PLWHA came for dental check-ups.

One study showed that an HIV-infected person has a greater risk for dental caries than those not infected with HIV, due to salivary gland enlargement and decreased function of the salivary glands. In HIV patients, there is a progressive decrease in CD $4+\mathrm{T}$ lymphocytes that can alter salivary flow and damage the immune system resulting in increased colonization of bacteria in the oral cavity suggesting that cariogenic bacteria are also increasing. ${ }^{5}$

Caries is one of the diseases in the oral cavity that prevalence in Indonesia is still quite high. It is an infectious disease of tooth tissue that affects the enamel, dentine, and cementum often caused by microbial activity on a fermented carbohydrate. The speed of acid formation by Streptococcus mutans is associated with caries occurrence. ${ }^{5}$

The increase in dental caries may be attributed to the decreased immune-competence of the HIV infected individual as has been found in other immunocompromised conditions. The influence of saliva on the caries process is fundamental; in some way, saliva affects all three components of Keye's classic Venn diagram of caries etiology (that is, tooth, plaque, and substrate). Salivary flow rates, clearance, $\mathrm{pH}$, buffer capacity, calcium phosphate homeostasis, effects on bacterial metabolism, adsorption to oral tissues and elimination from the oral cavity are all obvious manifestations of the saliva/caries interaction. Many studies have attempted to relate certain aspects of salivary output and composition to caries susceptibility. ${ }^{6}$

We conducted a survey to the patients visiting the Sememi Public Health Centre to find out if they have high Decayed, Missing, and Filled Teeth (DMFT) scores. Using the data we gathered, we identified our key population to determine and understand the factors influencing dental caries in HIV/AIDS patients.

\section{MATERIALS AND METHODS}

This is a descriptive, cross-sectional study on 16 individuals, selected using the total sampling method, who are identified to be HIV-seropositive from the HIV community of Sememi, Surabaya. They were asked to answer and complete a questionnaire, undergo an oral examination, and saliva collection. We adapted and utilized two questionnaires: 1 . the WHO's questionnaire on oral health and 2. WHO's questionnaire to measure the quality of life. ${ }^{7}$ The caries status of all participants were examined according to DMFT indices. For the stimulated saliva test, participants chewed a sterilized cotton ball for five minutes, and then they were asked to sit in an upright position with the head inclined forward so that the production of saliva is collected in the floor of the mouth and then flows out over the lip. Saliva formed is let to drip into the graduated test tube or a measure-cup for 15 minutes. Whole stimulated saliva samples were collected into a falcon tube. The reference values for stimulated saliva are: $(\mathrm{ml} /$ minute) more than 1.0 is normal, $0.7-1.0$ is low, and less than 0.7 is very low. ${ }^{8}$ The data presented in crosstab form between variables.

\section{RESULTS}

Frequency distribution of characteristics of the subjects is presented in Table 1. Demographic data shows that most of the respondents are $>30$ years old, males, and has not been married yet. Most of the respondents are Madura tribes (62.5\%), and have low income. But surprisingly, most of the respondents (56.3\%) are highly educated. Based on the HIV/AIDS knowledge background, most of the respondents have good knowledge and attitude on their diagnosis and the disease process itself. Most of the respondents have bad behavior on HIV/AIDS but a fair knowledge, attitude, and behavior towards dental caries. The summary of the characteristics of the respondents is shown in Table 2.

Further, 56.3\% respondents who have low knowledge towards caries, tend to have high dental caries prevalence. Eight of nine respondents that have low saliva flow rate have high dental caries prevalence $(\mathrm{OR}=0.313)$. Whereas, most of the respondents have good dental behavior and attitude (43.85\%) and yet still have high dental caries prevalence (Table 3).

\section{DISCUSSION}

Based on the results of the DMFT distribution data by the income of HIV-infected group, the poor socioeconomic transition of Puskesmas Sememi region which earns less than the minimum wage has a high level of caries (56.3\%). The high percentage of the group is in line with Ceylan's (2004) statement in his journal that caries is a good benchmark for socio-economic development, which can be seen in the high DMFT score in countries with poor socioeconomic transitions.

Knowledge is a very important domain for someone's actions formation (overt behavior) and studies prove that knowledge-based behavior will be more durable (longlasting) than behavior that isn't based on knowledge. ${ }^{9}$ The level of knowledge observed in this study includes knowledge of dental caries. Results from the questionnaire show a score of below average for most of the respondents. Knowledge of oral hygiene was also assessed in relation to severity of dental caries, and $56.3 \%$ of the respondents had high caries. 
Table 1. Characteristics distribution of respondents $(n=16)$

\begin{tabular}{|c|c|c|c|}
\hline Variable & Category & Frequency* & Percentage (\%) \\
\hline \multirow{2}{*}{$\begin{array}{c}\text { Status of } \\
\text { Respondents }\end{array}$} & Non PLWHA & 0 & 0 \\
\hline & ODHA & 16 & 100 \\
\hline \multirow{2}{*}{ Education } & $<$ High School & 7 & 43.75 \\
\hline & $\geq$ High School & 9 & 56.25 \\
\hline \multirow{2}{*}{ Age } & $\leq 30$ years & 5 & 31.25 \\
\hline & $>30$ years & 11 & 68.75 \\
\hline \multirow{2}{*}{ Sex } & Female & 3 & 18.75 \\
\hline & Male & 13 & 81.25 \\
\hline \multirow{2}{*}{ Income } & $\leq 3,200,000$ & 13 & 81.25 \\
\hline & $>3,200,000$ & 3 & 18.75 \\
\hline \multirow{2}{*}{ Marital Status } & Not married & 13 & 81.25 \\
\hline & Married & 3 & 18.75 \\
\hline \multirow{2}{*}{$\begin{array}{l}\text { Knowledge } \\
\text { toward HIV }\end{array}$} & Low & 4 & 25 \\
\hline & High & 12 & 75 \\
\hline \multirow{2}{*}{ Attitude toward HIV } & Low & 0 & 0 \\
\hline & High & 16 & 100 \\
\hline \multirow{2}{*}{$\begin{array}{l}\text { Behavior } \\
\text { toward HIV }\end{array}$} & Wrong & 14 & 87.50 \\
\hline & Right & 2 & 12.50 \\
\hline \multirow{2}{*}{$\begin{array}{l}\text { Knowledge } \\
\text { toward Caries }\end{array}$} & Low & 16 & 100 \\
\hline & High & 0 & 0 \\
\hline \multirow{2}{*}{$\begin{array}{l}\text { Attitude toward } \\
\text { Caries }\end{array}$} & Bad & 3 & 18.75 \\
\hline & Good & 13 & 81.25 \\
\hline \multirow{2}{*}{$\begin{array}{c}\text { Behavior toward } \\
\text { Caries }\end{array}$} & Wrong & 4 & 25 \\
\hline & Right & 12 & 75 \\
\hline \multirow{2}{*}{ Oral Hygiene } & Bad & 16 & 100 \\
\hline & Good & 0 & 0 \\
\hline \multirow{2}{*}{$\begin{array}{l}\text { How to brush } \\
\text { the teeth }\end{array}$} & Wrong & 6 & 37.50 \\
\hline & Right & 10 & 62.50 \\
\hline \multirow{2}{*}{$\begin{array}{c}\text { The reason to } \\
\text { the dentist }\end{array}$} & Sick & 2 & 12.5 \\
\hline & Not Come & 14 & 87.5 \\
\hline \multirow{2}{*}{$\begin{array}{l}\text { The reason not to } \\
\text { go to the dentist }\end{array}$} & Afraid & 2 & 12.5 \\
\hline & No complaints & 14 & 87.5 \\
\hline \multirow{2}{*}{ Flow Rate } & Low & 9 & 56.25 \\
\hline & Normal & 7 & 43.75 \\
\hline \multirow{2}{*}{ DMFT } & Low & 7 & 43.75 \\
\hline & High & 9 & 56.25 \\
\hline \multirow{5}{*}{ DMFT Category } & Very low & 2 & 12.50 \\
\hline & Low & 1 & 6.25 \\
\hline & Average & 3 & 18.75 \\
\hline & High & 6 & 37.50 \\
\hline & Very high & 4 & 25 \\
\hline \multirow{2}{*}{$\begin{array}{l}\text { The correlation } \\
\text { between DMFT and } \\
\text { saliva flow rate }\end{array}$} & Low & 3 & 18.75 \\
\hline & High & 13 & 81.25 \\
\hline
\end{tabular}

Furthermore, the overall score of good attitudes toward caries is $81 \%$. However a good attitude is not supported by a good caries risk outcome. Nine out of the 16 respondents have high severity of dental caries. However, actions or interventions to eliminate caries is around 43\%, but this is inversely proportional to the severity of caries in the population. Good attitude and correct action on the
Table 2. Cross-tabulation between HIV status and characteristics of the subjects

\begin{tabular}{lcccccc} 
& & \multicolumn{4}{c}{ HIV Status } & Odd \\
\cline { 3 - 6 } & & Negative & Positive & Ratio \\
\hline Age & 5 & 0 & $0 \%$ & 5 & $31.3 \%$ & \\
$\quad<30$ years & 11 & 0 & $0 \%$ & 11 & $68.8 \%$ & - \\
$\quad>30$ years & & & & & & \\
\hline $\begin{array}{l}\text { Occupation } \\
\quad \text { Prostitution }\end{array}$ & 6 & 0 & $0 \%$ & 6 & $37.5 \%$ & - \\
$\quad$ Maduranes & 10 & 0 & $0 \%$ & 10 & $62.5 \%$ & - \\
\hline Sex & & & & & & \\
$\quad$ Female & 3 & 0 & $0 \%$ & 3 & $18.8 \%$ & - \\
$\quad$ Male & 13 & 0 & $0 \%$ & 3 & $81.3 \%$ & - \\
\hline Income & 13 & 0 & $0 \%$ & 13 & $81.3 \%$ & - \\
$\quad<3,200,000$ & 3 & 0 & $0 \%$ & 3 & $18.8 \%$ & - \\
$\quad>3,200,200$ & & & & & & \\
\hline Education & 7 & 0 & $0 \%$ & 7 & $43.8 \%$ & - \\
$\quad<$ Senior High School & 9 & 0 & $0 \%$ & 9 & $56.3 \%$ & \\
$\quad>$ Senior High School & 9 & & & & & \\
\hline Marital Status & 13 & 0 & $0 \%$ & 13 & $81.3 \%$ & - \\
$\quad$ Not Married & 3 & 0 & $0 \%$ & 3 & $18.8 \%$ & \\
$\quad$ Married & & & & &
\end{tabular}

respondents are not in line with the high level of caries severity that occurs. This can be caused by several factors such as diet, drinking alcohol, smoking, and the immune system of respondents themselves.

Oral hygiene is also influenced by factors such as tooth brushing behavior, oral hygiene, wrong habitual of maintaining oral hygiene, individual characteristics such as age and sex, all of which can affect tooth decay rates or DMFT index. Data obtained showed that $100 \%$ of respondents have poor oral hygiene maintenance.

Statistics show that males have more caries than females. This is because sex variations or gender can influence the behavior patterns and oral health practices of a person in maintaining oral hygiene as well as the desired aesthetic needs. ${ }^{10}$

Education is a process of changing attitudes and behavior of a person or group that is an effort to mature humans through the efforts of teaching and training. ${ }^{11} \mathrm{~A}$ person whose education is low does not mean absolute low knowledge. A person's knowledge of an object contains two aspects, positive and negative aspects. According to the data obtained, high school is the last education most respondents obtained while some of them even went beyond high school education. However, in the category of caries severity, the result is higher (56.25\%) in respondents who have graduated from high school.

The flow rate and DMFT index were correlated with low flow rate $(<1 \mathrm{ml} / \mathrm{min})$. This supports the theory that changes in saliva flow rate will affect the function of saliva which plays an important role in maintaining oral health and prevent caries ${ }^{12}$ through several activities like clearance 
Table 3. Cross-tabulation between caries and characteristics of the subjects

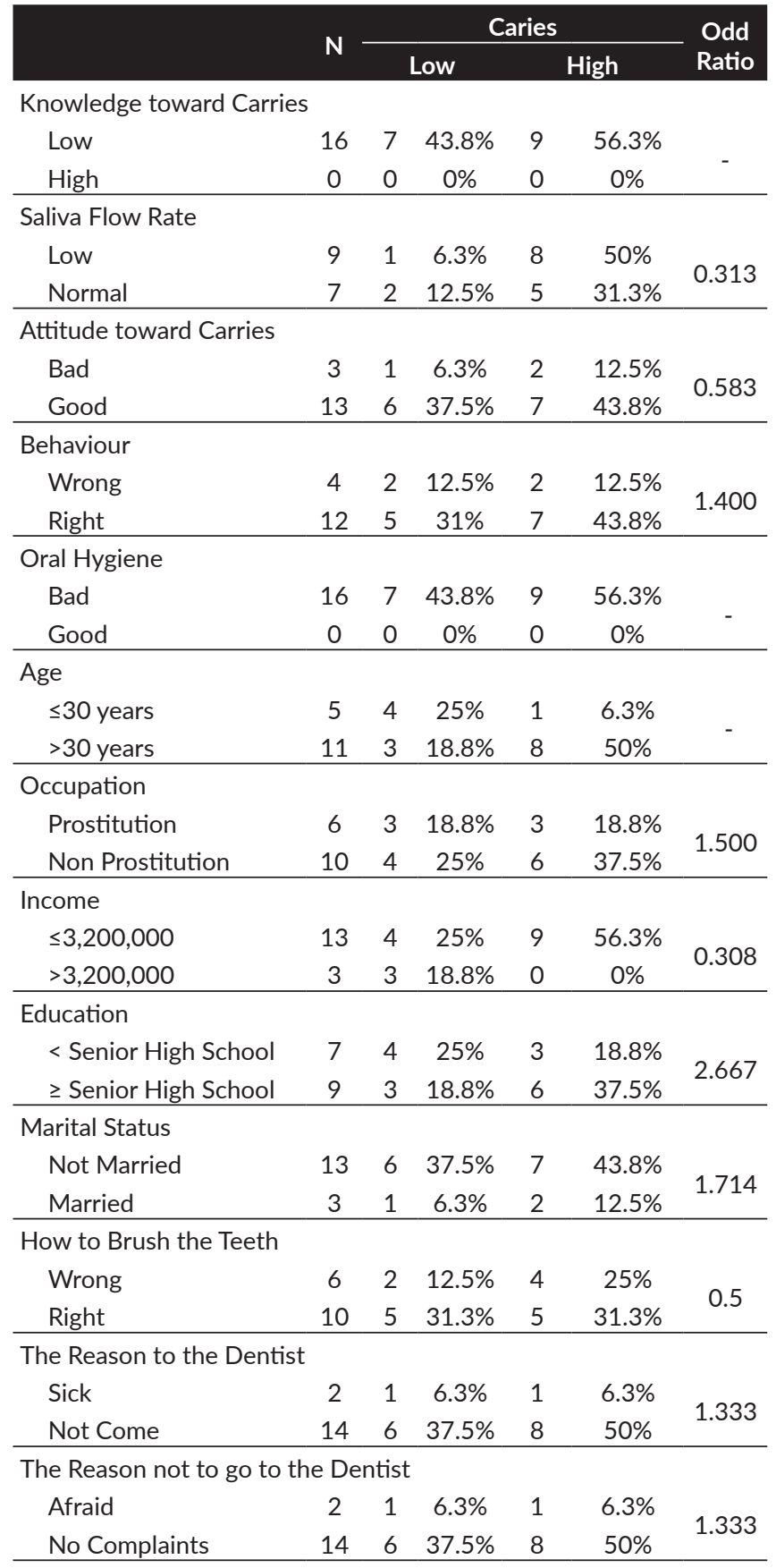

effects, buffering capacity, increased remineralization, and the ability to produce antibodies. ${ }^{13}$

Low salivary flow rate will decrease the concentration of bicarbonate so that the buffer capacity decreases and will create xerostomia (dry mouth) conditions which will increase the risk of caries. ${ }^{14}$ The optimum saliva acidity $(\mathrm{pH})$ to inhibit bacterial growth between 6.5-7.5 and when a low $\mathrm{pH}$ (between 4.5-5.5) will facilitate the growth of asidogenic germs such as S. mutans. In addition, a decrease in $\mathrm{pH}$ within the oral cavity can cause rapid demineralization of tooth elements. ${ }^{15}$
Incomes which are less or equal to the minimum regional wage are associated with caries occurrence and a reflection of social inequality. ${ }^{15}$ The relationship between income and DMFT index was determined by obtaining the majority income of the respondents, which is less than Rp 3.200.000 with those having a high category of DMFT index. According to Bastos and Szwarcwald, the poor people are vulnerable to infectious diseases linked to social and biological reasons, as well as factors related to infection prevention such as low resources, low levels of education, inactivity, and inequalities in health access. ${ }^{16}$

\section{CONCLUSION}

This study shows that subjects with HIV/AIDS have high DMFT and low salivary flow rate.

\section{Acknowledgments}

The authors thank the Department of Dental Public Health, Faculty of Dental Medicine, Universitas Airlangga and Puskesmas Sememi Surabaya.

\section{Statement of Authorship}

All authors participated in data collection and analysis, and approved the final version submitted.

\section{Author Disclosure}

All authors declared no conflict of interest.

\section{Funding Source}

None.

\section{REFERENCES}

1. Astindari A, Lumintang H. Ways of Transmitting HIV \& AIDS in the Infectious Disease Intermediate Care Unit (UPIPI) Dr. Soetomo Surabaya. Berkala Ilmu Kesehatan Kulit Kelamin (BIKKK). 2014; 26(1):36-40

2. Indonesia Health Ministry. Prevention and Controlling Disease. Jakarta: Directory of Health Ministry; 2016. pp.53-62

3. Suryaningdiah D. Recommendations Efforts to Improve Compliance with ARV Treatment in Surabaya City. Jurnal Penelitian Kesehatan Suara Forikes. 2016; 2(1):8-31.

4. Thomas S, Rahayu A, Alamudi MY, Hiv S, Thomas S, Rahayu A, et al. Skrining HIV pada Remaja di Surabaya dengan Menggunakan Rapid Test. MHSJ. 2017;1(2):57-62.

5. Fatmawati DWA. Relationship between Streptococcus mutans biofilm and the risk of dental caries. Jurnal Kedokteran Gigi Unej. 2011;8(3):127-130.

6. Malhotra A, Ahlawat J, Hegde MN, Mahajan A. Dental caries status in human immunodeficiency virus-positive and acquired immunodeficiency syndrome patients. Indian J Oral Sci. 2016; 7(2):103-6

7. Mooney A. Quality of life: Questionnaires and questions. J Health Commun. 2006 Apr-May; 11(3):327-41

8. Almstahl A, Finizia C, Carlen A, Fagerberg-Mohlin B, Alstad T. Explorative study on mucosal and major salivary secretion rates, caries and plaque microflora in head and neck cancer patients. Int J Dent Hyg. 2018 Nov; 16(4):450-8.

9. Notoatmodjo S. Health Promotion and Behaviour. Jakarta: Rineka Cipta; 2012. pp. 5-55. 
10. Haesman P. Master Dentistry. Vol 1. Philadelphia: Churchill Livingstone; 2003. pp. 35-75

11. Budiman Riyanto A. Kapita Selekta Knowledge Questionnaire and Attitudes in Health Research. Jakarta: Salemba Medika; 2013. pp. 66-69.

12. Sriningsih I. Demographic factors, mother's knowledge about mother's milk and exclusive breastfeeding. KEMAS. 2011;6(2):100-6.

13. Rezaei-Soufi L, Davoodi P, Abdolsamadi HR, Jazaeri M, Malekzadeh H. Dental caries prevalence in Human Immunodeficiency Virus infected patients receiving highly active anti-retroviral therapy in Kermanshah, Iran. Cell J. 2014 Feb; 16(1):73-8.
14. Indriana $\mathrm{T}$. Differences between salivary flow rate and $\mathrm{pH}$ due to the influence of chemical and mechanical stimuli. J Kedokt Meditek. 2011;17(44):1-5.

15. Pradanta YE, Adhani R, Khatimah IH. Relationship between $\mathrm{pH}$ and Volume of Saliva to Caries Index of Society of Angling Lokpaikat District, Tapin District. Dentino. 2016; 1(2):76-80.

16. Gonçalves ER, Peres MA, Marcenes W. Dental caries and socioeconomic conditions: A crosssectional study among 18 yearsold male in Florianópolis, Santa Catarina State, Brazil. Cad Saúde Pública. 2002 May-Jun; 18(3):699-706.

The Acta Medica Philippina is now accepting limited advertising for its front and back cover (colored), as well as for available spaces in some of its pages, as appropriate. For inquiries and submission of proposals, please e-mail us at actamedicaphilippina@yahoo.com 